\title{
Parent's attitude towards their mentally retarded children: A descriptive, cross-sectional, comparative and analytical study.
}

\author{
*Dr. Md. Shahedul Islam \\ Associate Professor, Dept. of Psychiatry, Cumilla Medical College, Cumilla. Mobile: 01712-261296 \\ Dr. Mohammad Masudur Rahman \\ Associate Professor, Dept. of Gastroenterology, Dhaka Medical College, Dhaka. Mobile: 01715-426422 \\ Dr. Md Harun Ar Rashid \\ Associate Professor, Dept. of Psychiatry, Cumilla Medical College, Cumilla. Mobile: 01552475798
}

Dr. Md Forhad Abedhan

Resident Physician, Cumilla Medical College Hospital, Cumilla. Mobile: 01716-741473

Dr. Md Shamsuzzaman Prodhan

Junior Consultant (Paediatric), GangacharaUHC, Rangpur. Mobile: 01716808704

\author{
Dr. Md. Abul Bashar \\ Senior Consultant, Dept. of Paediatric, Cumilla Medical College Hospital, Cumilla. Mobile: 01711-353493
}

Prof. Dr. Md. Nizam Uddin

Professor and Head, Dept. of Psychiatry, Cumilla Medical College, Cumilla. Mobile: 01711-153778

\section{Address of Correspondence}

Dr. Md. Shahedul Islam, Associate Professor, Dept. of Psychiatry, Cumilla Medical College, Cumilla. Mobile: 01712261296, Email: dr.shahedislam@gmail.com

DOI: $10.31364 / S C I R J / v 7 . i 5.2019 . P 0519654$

http://dx.doi.org/10.31364/SCIRJ/v7.i5.2019.P0519654

\begin{abstract}
Parents attitudes toward their mentally retarded children are of paramount importance, because majority of such children are looked after at their home and parental attitude determines the efficiency and adequacy of the training measures to be adopted by the parents. Attitudes are determined by social influences, cognitive influences, behavioral influences etc. These influences jointly mold our earliest attitudes, and they can change our attitudes through our lives. Attitude strongly affect how a person perceive and respond to other people including their mentally retarded children. Unrealistic and self-defeating attitudes lead on to distort family interactions which greatly hampers. A descriptive cross-sectional and analytical study was done in Department of Psychiatry, Cumilla Medical College, Cumilla. All cases were selected from patients attending at Cumilla Medical College Hospital and Private Mental Health Facilities in Cumilla City from April 2014 to September 2017. The main objective of the present study was to investigate the attitudes of parents towards their mentally retarded children. Total 80 participants who fulfilled the enrolment criteria were included in the study. Wechsler Intelligence Scale for IQ assessment children (WISC-III) and Independent Adaptive Behavior Assessments Scale (IBAS) were used for diagnosing regarding mentally retarded children. A structural Likert- type Scale was used to assess the attitudes from the Parental Attitude Research Instrument (PARI) adapted by Schaefer \& Bell, (1958), Thurstone (1959) and Parekh (1988). Respondents provided sociodemographic information. The findings of this study revealed that most of the parents had relatively positive attitudes towards their mentally retarded children. Among the participants $42.50 \%$ of the mothers and $36.25 \%$ of the fathers in the present study expressed a positive attitude towards their mentally retarded children considering the total categorical score. Only $2.5 \%$ parents expressed a very negative attitude towards their mentally retarded children which was reflected by disappointment. In the light of these findings further research areas is recommended with the aim of using such information to build appropriate and successful rehabilitation and intervention programs for mentally retarded children and their parents.
\end{abstract}

Key Words: Attitudes, MR children, love and acceptance, embarrassment, frustration, disappointment, over-protection. 


\section{Introduction}

Attitudes are determined by social influences, cognitive influences, behavioral influences etc. These influences jointly mold our earliest attitudes, and they can change our attitudes through our lives. Attitude strongly affect how a person perceive and respond to other people including their mentally retarded children. Parent's attitudes toward their mentally retarded children are very important. Unrealistic and self-defeating attitudes lead on to distorted family interactions which greatly hampers the already current learning processes of the child and at times, precipitate severe emotional problem in both the parents. ${ }^{1}$ The essential features of mental retardation is significantly sub-average general intellectual functioning that is accompanied by significant limitations in adapting functioning in at least two of the skill areas such as communication, self care, home living, social/ interpersonal skills, use of the community resources, self-direction, functional academic skills, work, leisure, health and safety. The onset must occur before age 18 years. $^{2}$ Some children with mentally retarded are not identified with problems until school age, because they make relatively few demands and have minimal conflicts with others owing to their infrequent social engagement. ${ }^{2}$ The prevalence of Mental Retardation has been estimated at approximately $1 \%$. However, different studies have reported different rates depending on definitions used, methods of ascertainment and population studied. Over $85 \%$ of the World's disable children less than 15 years of age live in developing countries. ${ }^{3}$ In Bangladesh, Mental retardation (3.8\%) were prevalent in the young children age group of 5 to 17 years according to the DSM- IV TR. ${ }^{4}$

The fact that attitudes are not static presents the greatest aid to therapy. Most parents can be helped to express, recognize and eventually modify their attitudes for the mutual benefit of themselves and their children. ${ }^{5}$ Several studies revealed that there was link between mental retardation and autism which provided evidence that autism is a pervasive developmental disorder with a neurological basis. ${ }^{6}$ Parents passes through different emotional stages after the birth of a mentally retarded child, such as ambivalence and anger and that followed by denial and sadness. Then gradually parents will enter an adaptation stage when they, for example, begin to ask questions about what can be done, and finally a reorganization stage when they seek help and begin to plan ahead. ${ }^{8}$ Parental attitudes are influenced by a number of factors such as, whether the handicap is evident at birth or later; whether there is a prospect of severe mental handicap or not; whether the handicap is obvious to other people and by the attitudes of other people such as lay people, teachers, social workers, and doctors to handicap and handicapped people. ${ }^{9}$ Parents of scholars have a more optimistic attitude regarding the future functioning and independence of their children than parents of non-scholars. ${ }^{10}$

\section{Methods}

A descriptive cross-sectional study was done in Depatrment of Psychiatry, Cumilla Medical College, Cumilla. All cases were selected from patients attending at Cumilla Medical College Hospital and Private Mental Health Facilities in Cumilla City from April 2014 to September 2017. Duration of study was two and half year. Total 92 parents were approached for interview. Considering inclusion and exclusion criteria, finally 80 participants who fulfilled the enrolment criteria were included in the study. Convenience sampling technique was applied. Age of the mentally retarded children was within 18 years. Semi structured questionnaire included information of the parents of mentally retarded children, and the family environment were used to collect the sociodernographic and relevant information of the respondent. Wechsler Intelligence Scale for IQ assessment children (WISCIII) and Independent Adaptive Behavior Assessments Scale (IBAS) were used for diagnosing regarding mentally retarded children. A structural Likert- type Scale was used to assess the attitude from the Parental Attitude Research Instrument (PART) adapted by Schaefer \& Bell, (1958), Thurstone (1959) and Parekh (1988). Questions were designed to provide information on parent behaviour; love and acceptance, embarrassment, frustration, disappointment, and over-protection which was the definition of attitude used in this study. The questionnaire was first translated into Bengali by an English expert speaking post graduate psychologist. This translation was then checke another English expert. DSM-5 was used to diagnose the psychiatric disorders. Semi structural questionnaire were used for collecting sociodemographic information. All collected data were checked and verified thoroughly for consistency as well as for completeness. Finally appropriate statistical analysis was done with SPSS 
version 19 to see the trends of the data. Frequency tables, summary tables and appropriate graphs were prepared to describe the population characteristics and study finding.

\section{Results}

A participation rate was found $47.5 \%$ male and 52.5\% female. All participants were adult. A psychiatric disorder was 78 (65\%). Majority of the participants were married, and come from educated and middle class families. Among mentally retarded children, boys and girls were $63.75 \%$ and $36.25 \%$ respectively.

Table 1: Parents sex category of total score crosses tabulation

\begin{tabular}{cccccccc}
\hline Parents & \multicolumn{3}{c}{ Category of total score } & Total & Chi-Square & P value & $\begin{array}{c}\text { Signifi- } \\
\text { cance }\end{array}$ \\
\hline Father & 9 & 28 & 1 & 38 & 0.26 & 0.87 & $\begin{array}{c}\text { Non-signific } \\
\text { Post (ns) }\end{array}$ \\
Mother & 8 & 33 & 1 & 42 & & \\
Total & 17 & 61 & 2 & 80 &
\end{tabular}

Table showed that the statistically non-significant differences between the attitudes of mothers and fathers towards MR children (P value 0.87 ).

Table-2: Education status of parents and attitude towards their MR children.

\begin{tabular}{|c|c|c|c|c|c|c|c|c|c|}
\hline \multirow{2}{*}{$\begin{array}{c}\text { Parents } \\
\text { education }\end{array}$} & \multicolumn{3}{|c|}{ Category of total score } & \multirow[b]{2}{*}{ Positive } & \multirow{2}{*}{$\begin{array}{c}\text { Very } \\
\text { positive }\end{array}$} & \multirow[b]{2}{*}{ Total } & \multirow{2}{*}{$\begin{array}{c}\text { Chi } \\
\text { Square } \\
\text { value }\end{array}$} & \multirow[b]{2}{*}{ p value } & \multirow{2}{*}{$\begin{array}{l}\text { Signif- } \\
\text { icance }\end{array}$} \\
\hline & $\begin{array}{c}\text { Very } \\
\text { negative }\end{array}$ & Negative & $\begin{array}{l}\text { Not } \\
\text { sure }\end{array}$ & & & & & & \\
\hline Illiterate & 00 & 00 & 05 & 11 & 01 & 17 & \multirow{6}{*}{4.06} & \multirow{6}{*}{0.85} & \multirow{6}{*}{ ns } \\
\hline Primary & 00 & 00 & 03 & 15 & 00 & 18 & & & \\
\hline Secondary & 00 & 00 & 05 & 17 & 00 & 22 & & & \\
\hline $\begin{array}{c}\text { Higher } \\
\text { Secondary }\end{array}$ & 00 & 00 & 01 & 05 & 00 & 06 & & & \\
\hline Higher & 00 & 00 & 03 & 13 & 01 & 17 & & & \\
\hline Total & 00 & 00 & 17 & 61 & 02 & 80 & & & \\
\hline
\end{tabular}

Table 3: Marital status of parents and attitude towards their MR children

\begin{tabular}{|c|c|c|c|c|c|c|c|c|c|}
\hline \multirow{2}{*}{$\begin{array}{c}\text { Family } \\
\text { marital } \\
\text { situation }\end{array}$} & \multicolumn{3}{|c|}{ Category of total score } & \multirow[b]{2}{*}{ Positive } & \multirow{2}{*}{$\begin{array}{c}\text { Very } \\
\text { positive }\end{array}$} & \multirow[b]{2}{*}{ Total } & \multirow{2}{*}{$\begin{array}{c}\text { Chi } \\
\text { Square } \\
\text { value }\end{array}$} & \multirow[b]{2}{*}{ p value } & \multirow{2}{*}{$\begin{array}{l}\text { Signif- } \\
\text { icance }\end{array}$} \\
\hline & $\begin{array}{c}\text { Very } \\
\text { negative }\end{array}$ & Negative & $\begin{array}{l}\text { Not } \\
\text { sure }\end{array}$ & & & & & & \\
\hline Married & 00 & 00 & 15 & 54 & 2 & 71 & & & \\
\hline Widowed & 00 & 00 & 02 & 06 & 0 & 08 & & & \\
\hline Divorced & 00 & 00 & 00 & 01 & 0 & 01 & 0.60 & 0.96 & ns \\
\hline Separated & 00 & 00 & 00 & 00 & 0 & 00 & & & \\
\hline Total & 00 & 00 & 17 & 61 & 2 & 80 & & & \\
\hline
\end{tabular}

Table showed that the marital status of parents with attitude towards MR children were non-significant (P value 0.96). 
Table-4: Economical status of parents and attitude towards MR children.

\begin{tabular}{|c|c|c|c|c|c|c|c|c|c|}
\hline \multirow{2}{*}{$\begin{array}{c}\text { Parents } \\
\text { Economical } \\
\text { status }\end{array}$} & \multicolumn{3}{|c|}{ Category of total score } & \multirow[b]{2}{*}{ Positive } & \multirow{2}{*}{$\begin{array}{c}\text { Very } \\
\text { positive }\end{array}$} & \multirow[b]{2}{*}{ Total } & \multirow{2}{*}{$\begin{array}{c}\text { Chi } \\
\text { Square } \\
\text { value }\end{array}$} & \multirow[b]{2}{*}{$\begin{array}{c}\mathbf{p} \\
\text { value }\end{array}$} & \multirow{2}{*}{$\begin{array}{l}\text { Signif- } \\
\text { icance }\end{array}$} \\
\hline & $\begin{array}{c}\text { Very } \\
\text { negative }\end{array}$ & Negative & $\begin{array}{l}\text { Not } \\
\text { sure }\end{array}$ & & & & & & \\
\hline Low class & 00 & 00 & 11 & 33 & 00 & 44 & & & \\
\hline Middle class & 00 & 00 & 06 & 24 & 02 & 32 & 4.54 & 0.33 & ns \\
\hline High class & 00 & 00 & 00 & 04 & 00 & 04 & & & \\
\hline Total & 00 & 00 & 17 & 61 & 02 & 80 & & & \\
\hline
\end{tabular}

Table showed that the economical status of parents with attitude towards MR children were non-significant (P value 0.33 )

Table 5: Distribution if sexual differences of MR children and parents attitude

\begin{tabular}{|c|c|c|c|c|c|c|c|c|c|}
\hline \multirow{2}{*}{$\begin{array}{c}\text { Sex of } \\
\text { disabled } \\
\text { child }\end{array}$} & \multicolumn{3}{|c|}{ Category of total score } & \multirow[b]{2}{*}{ Positive } & \multirow{2}{*}{$\begin{array}{c}\text { Very } \\
\text { positive }\end{array}$} & \multirow[b]{2}{*}{ Total } & \multirow{2}{*}{$\begin{array}{c}\text { Chi } \\
\text { Square } \\
\text { value }\end{array}$} & \multirow[b]{2}{*}{$p$ value } & \multirow{2}{*}{$\begin{array}{l}\text { Signif- } \\
\text { icance }\end{array}$} \\
\hline & $\begin{array}{c}\text { Very } \\
\text { negative }\end{array}$ & Negative & $\begin{array}{l}\text { Not } \\
\text { sure }\end{array}$ & & & & & & \\
\hline Boy & 00 & 00 & 08 & 42 & 01 & 51 & & & \\
\hline Girl & 00 & 00 & 09 & 19 & 01 & 29 & 5.85 & 0.21 & $\mathrm{~ns}$ \\
\hline Total & 00 & 00 & 17 & 61 & 02 & 80 & & & \\
\hline
\end{tabular}

Table showed that the parents' attitude with sexual differences of MR children were non-significant (P value 0.21$)$.

Table 6: Physical disorders of MR children and parents attitude

\begin{tabular}{lcccc}
\hline & Frequency & Percent & P value & Significance \\
Yes & 25 & 31.25 & & \\
No & 55 & 68.75 & .001 & Significance \\
Total & 80 & 100.00 & &
\end{tabular}

Table showed that the parents' attitude with Physical disorders of MR children were significant (P value 0.001).

Table 7: Distribution Category of total score

\begin{tabular}{lccccc}
\hline $\begin{array}{l}\text { Category of } \\
\text { total score }\end{array}$ & $\mathbf{A}$ & $\mathbf{B}$ & $\mathbf{C}$ & $\mathbf{D}$ & $\mathbf{E}$ \\
$\begin{array}{l}\text { Attitude } \\
\text { Number of }\end{array}$ & Very negative & Negative & Not sure & Positive & Very positive \\
$\begin{array}{c}\text { respondents } \\
\text { Percentage of }\end{array}$ & 0 & 0 & 17 & 61 & 2 \\
respondents & 0 & 0 & 21.5 & 76.25 & 2.5 \\
\hline
\end{tabular}

The table showed that the $76.25 \%$ of the parents in the present study expressed within the D category, which indicates positive attitude. $2.50 \%$ of the parents expressed within the E category indicating a very positive attitude.78.75\% of the parents in the present study expressed a positive attitude. Only $21.25 \%$ of the parents fall within the Category which indicates a not-sure attitude? There were no parents in the A or very negative and B or negative categories. 
Figure 1: Category of love and acceptance

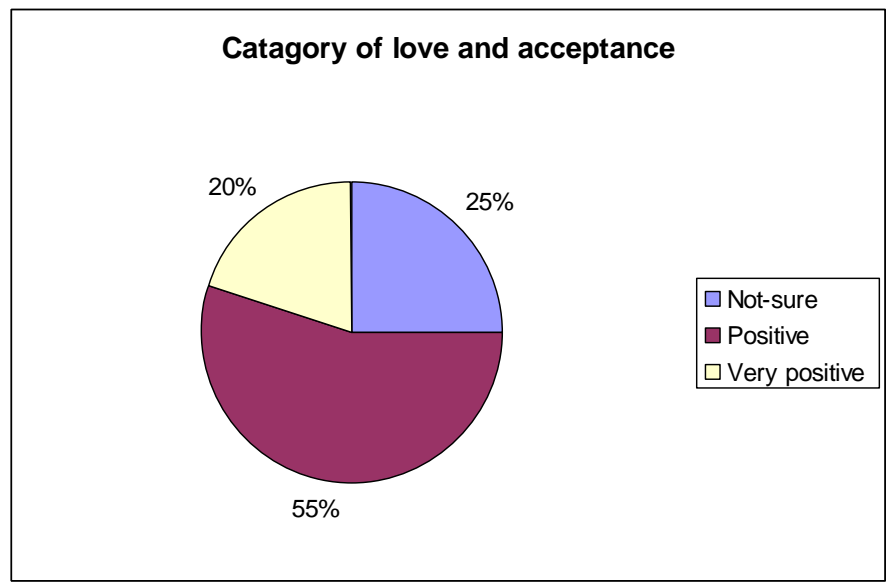

Figure 2: Category of embarrassment

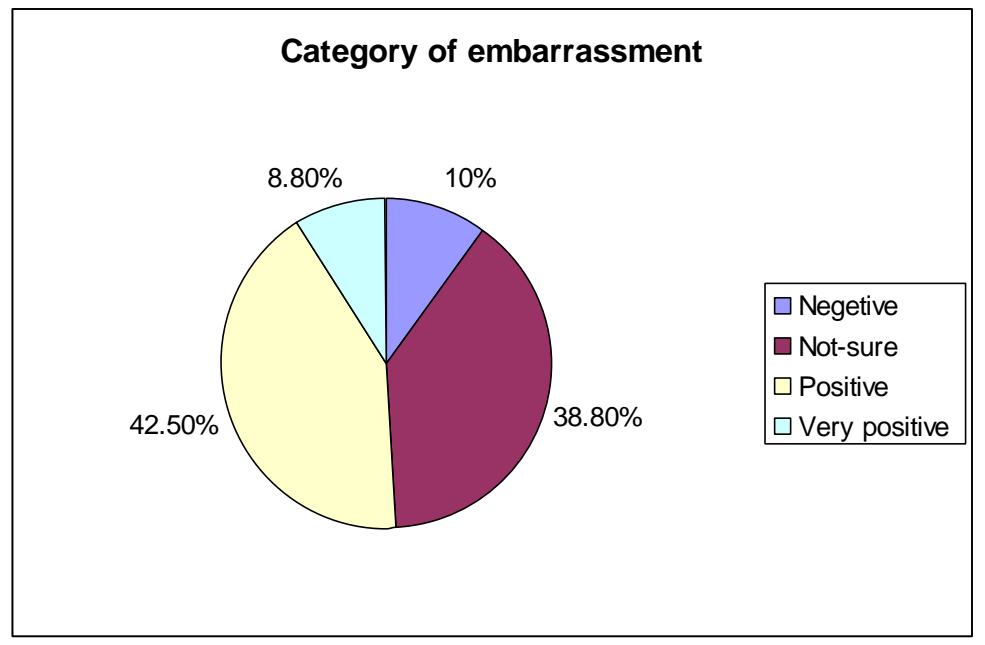

Figure 3: Category of frustration

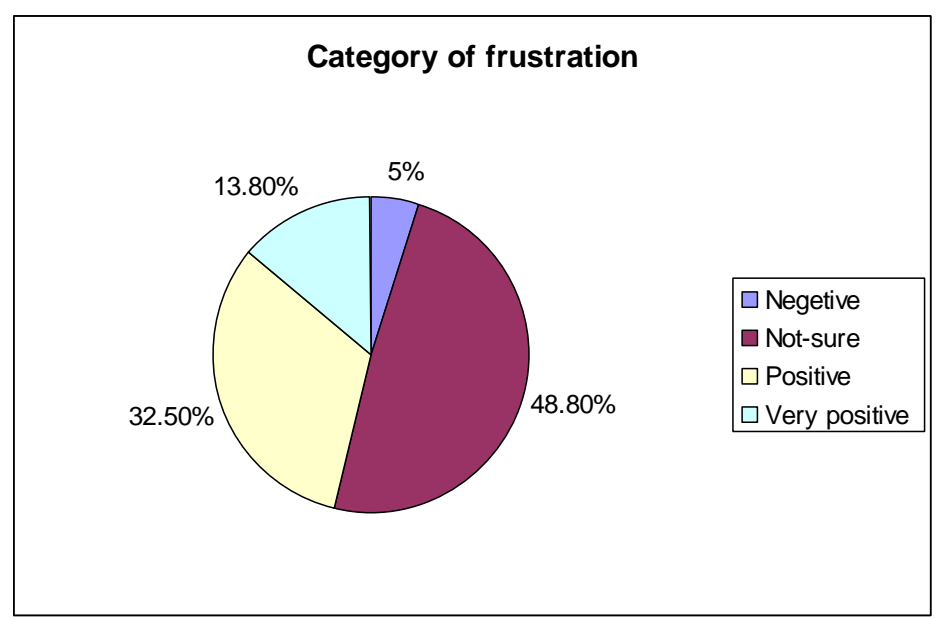

www.scirj.org

(C) 2019, Scientific Research Journal 
Figure 4: Category of disappointment

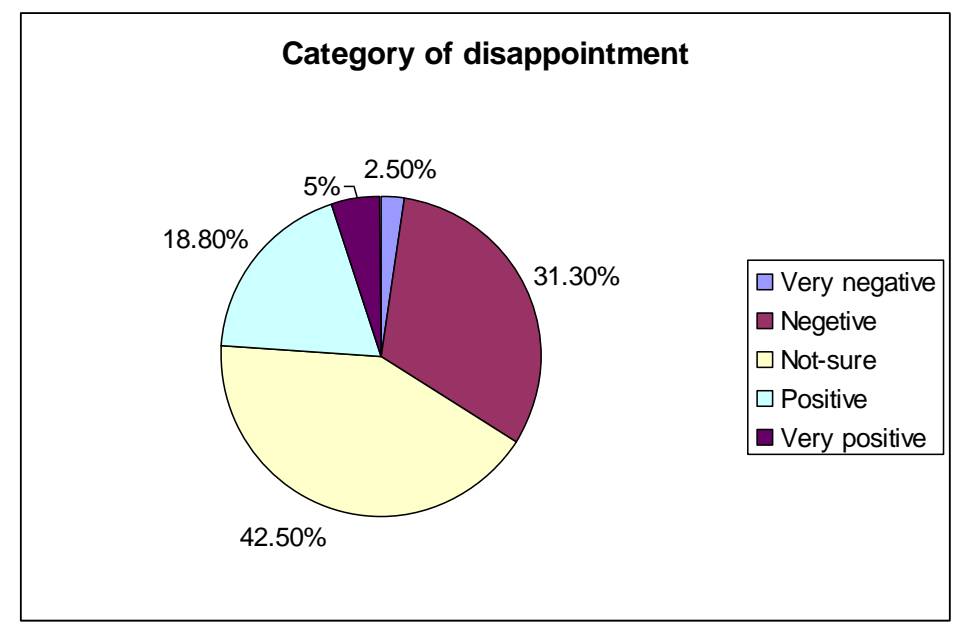

Figure 5: Category of over-protection

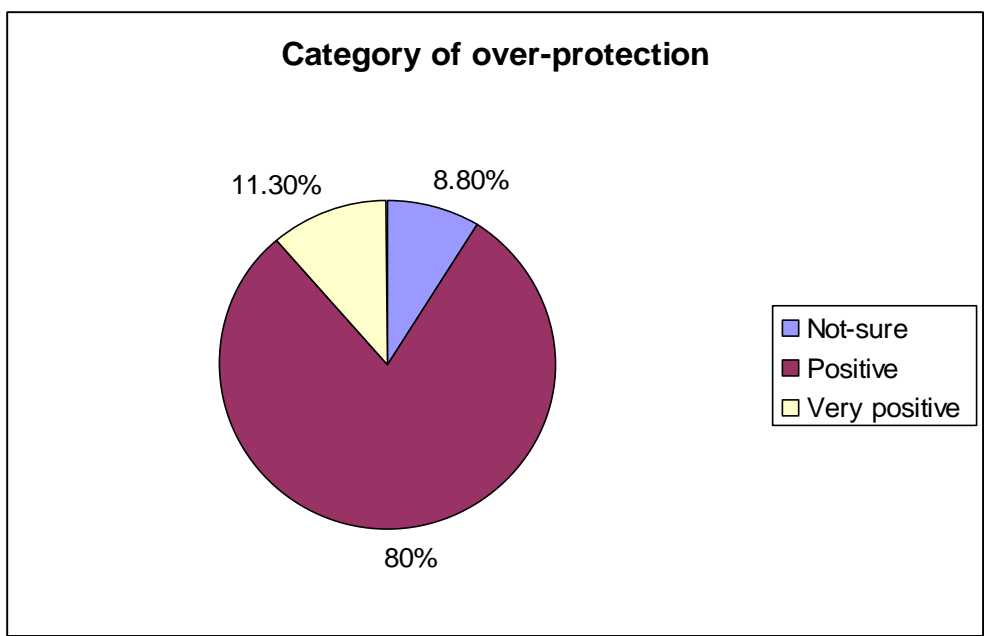

\section{Discussion}

The majority of parents in different areas found to have a positive attitude towards their mentally retarded children although a small proportion of parents had a negative attitude. There were no parents found to have a strongly negative and negative attitude. There were no differences between the attitudes of mothers and fathers among autistic children. Most of the mothers and fathers displayed positive attitudes. It has been observed in the present study. But previous study showed that the most mothers displayed positive attitudes than fathers. ${ }^{7}$

There was no parent that expressed very negative attitudes and $21.5 \%$ of parents expressed within a not-sure attitude towards their MR children considered as total categorical score. This finding was not observed in the previous study. Only $16 \%$ of parents expressed negative attitude towards their MR children considered as total categorical score in previous study. ${ }^{7}$ Another important finding of this study concerns the fact, $75 \%$ of the parents in the present study expressed a positive attitude considering only love and acceptance subscale. In the previous study no mother showed negative attitude. ${ }^{7}$ Where $38.8 \%$ of the respondents expressed a not-sure, $10 \%$ of the respondents expressed a negative and $51.3 \% \%$ of the respondents expressed a positive attitude reflected by embarrassment subscale towards MR children which were not coincide with previous study. ${ }^{7}$ 
About $33 \%$ of the of the respondents expressed a positive, $48.8 \%$ of the respondents expressed a not-sure and only $5 \%$ of the respondents expressed a negative attitude reflected by frustration subscale towards MR children which were not coincide with previous study. Where as $11 \%$ of very negative and $8 \%$ of negative attitudes of the respondents expressed by frustration subscale towards MR children which were observed in previous study which were not coincide with present study. ${ }^{7} 31.3 \%$ of the of the respondents expressed a negative, $23.8 \%$ of the respondents expressed a positive and only $42.5 \%$ of the respondents expressed a not-sure attitude reflected by disappointment subscale towards MR children which were not typical coincide with previous study. Only $2.5 \%$ respondents in the present study expressed a very negative attitude towards MR children reflected by disappointment subscale which were not observed in previous study. ${ }^{7}$ It has been observed in the present study, a high number (91.3\%) of the parents expressed a positive attitude towards their MR children that was reflected by overprotection subscale. Those results were near about similar of the previous study. There were no respondents expressing negative or very negative attitudes reflected by over-protection that were observed in previous study. ${ }^{7}$ The result of present study are not typical coincide with previous study due to economical variable, cross cultural difference, geographical variation, health care opportunities, different study time and place, and a family system. Respondents coming only from rural area were selected for study group in previous study that differed from present study. Respondent's sex, educational level, occupation, marital, and economical status and MR Child sex were not affect the attitudes. Only physical disorders of MR children were affect the attitudes where significance P value- 0.001 .

The positive attitudes of parents towards their MR children were reflected by family bonding, cohesive family system, strong religious believers and cultural influences in our country. Bangladesh is a religious bonding country. Religious believe encourages showing helpful, empathic and respectful attitude towards MR children. ${ }^{8}$ These possible explanations could be accepted considering mentioned factors minor variation from previous study finding.

The highest number of parents was being positive towards their MR children. Although a small proportion of parents had a negative attitude. Due to the extended family system the responsibility of caring for autistic child is shared. Now a day because of urbanization and breakdown of the extended family, autistic children are not easily accepted. Therefore, this further limits the extent to which the findings can be generalized. Further studies are required to confirm and elaborate findings of the present study. It has provided a basis for much needed similar research in other areas in our country.

\section{Conclusion}

The present study identified that the parents in different areas had positive attitudes towards their mentally retarded children. The findings of the study will help the parents and family members for better management of their MR children. A longitudinal follow-up study is required to give more reliable information in Bangladesh.

\section{REFERENCES}

1. Crider AB, Goethals GR, Kavanaugh RD, Solomon PR. Social Cognition. Psychology. 4th edition, New York: Harper Collins College Publishers.1 993; 12:430-432.

2. Diagnostic and statistical manual of mental disorders text revision. (4th Edition). American Psychiatric Association, Washington, DC.1994:41.

3. Kaplan HI \& Sadock BJ. Synopsis of psychiatry- behavioral science and clinical psychiatry. $11^{\text {th }}$ edition, Philadelphia: Lippincott Williams \& Wilkins. (2015); 34:1152-53.

4. Rabbani MG, Alum MF ShafiquI MS, Sarkar Prevalence of mental disorders, mental retardation, epilepsy and substance abuse children. Bang J Psychiatry. 2009; 23(1):34.

5. Ferdous S, Zaman SS, Khan NZ, Durkin M, Berg AL. Prevalence of childhood disability: The TQP study in Bangladesh. Bangladesh Protibondhi Foundation (BPF).2005:16-25.

6. Mullick MSI. Clinical profile of autism: A study of 56 cases, Bangladesh J Child Health.2000; 24(1): 6-14. 
7. Govender N. Attitudes of parents towards their mentally retarded children: a rural area examination. University of Zululand.

South Africa.January 2002:1-7.

8. Santosh K, Chaturvedi MD, Savita Malhort, MD, Summary MD. A follow-up study of mental retardation focusing on parental attitudes. Indian J Psychiatry. 1984; 26(4): 370-376.

9. McKeith R. The feelings and behavior of parents of handicapped children. Developmental Medicine and Child Neurology. 1973:15.

10. Govender M. An investigation into the social functioning of the physically disabled or chronically ill child with special reference to his educational needs. University of Durban Westville, KwaZulu Natal. 1984. 